\title{
'A story of a bird named Bìm Bịp': lies, violence, and meaning
}

\author{
Hồ Mạnh Toàn \\ Al for Social Data Lab \\ Hanoi, 30 September 2019
}

\begin{abstract}
"On the road, he met a bandit who was wielding a big sword. The monk was scared, but he thought the bandit would not harm him because he is a religious man. Suddenly, the bandit kneeled and asked: "The master, please accept me as your disciple. My hands filled with blood. I am ashamed and regretful. I don't know if I can still lead a religious life or not."
\end{abstract}

The monk assured him: "You need a true heart to lead a religious life. If you are truly penitent of your sins, The Devine will know for sure. I am on my way to meet the Buddha, so I cannot accept you as my disciple."

The bandit replied: "Please send my true heart to the Buddha." Then immediately, cut his chest open, took out his heart and gave it to the monk."

The violent action was done to the bandit by himself, and it was unexpected and somewhat irrational. The character who performs this action is also portrayed as an uneducated and barbaric man. Camus once asserted: "A man defines himself by his make-believe as well as his sincere impulses" [1]. The bandit was uneducated; therefore, we have no basis to doubt that his pursuit of forgiveness is an act of insincerity. To the best of his understanding, he also acts out on his sincere impulses with a fast cut. Even though we were never told about his inner thoughts, we can feel that the bandit is a man who defined himself clearly.

"The monk prayed for the thief, then he carried on with the heart of the dead. Slowly, the heart started to rot and became smelly, which attracted the flies. Eventually, the monk threw the heart away, thinking that the bandit will never be able to lead a religious life."

The dishonest action was done to the thief by the monk. In contrast with the bandit's action, the action of the monk is logical and rational. When you see a bandit, who would have thought that he possesses that quality to be enlightened. And, would any normal person carry a rotten heart with him?

The journey of the monk was carefully narrated with his inner thoughts; which suggests that he is not a bad man, but he is not entirely sincere either. His motive is never for other people. When the bandit begged for his teaching, he was too caught up with his own journey. Then, when the rotten heart disturbed him, he decided to throw it away. It is also noteworthy that the monk sees himself as a religious man, so the bandit would not rob or harm him. 
"The Buddha told the monk: "You have done a lot of good, but you still missing a cause. You go find the heart and bring it back to me. By then, you can find the enlightenment."

The monk came back to find the heart, from bushes to bushes. Eventually, he turned into a bird named Bim bịp. The color of its feathers is half black half brown, similar to the color of the monk's Buddhist coat."

Nonetheless, the bandit's irrational action leads him to enlightenment, while the monk spends eternity on finding the 'true heart.' It is remarkable how such a short story is layered with thoughtful structures and meaning. Even the choice to associate violence with the bandit and lies with the monk is an interesting setup. The violence is thoughtless, and it often turns into pure chaos. However, a lie is always planned and deployed for a clear motivation. When a man is violent, he often has no control; but when a man lies, he is often in control. Here, it is possible that the bandit is violent because his nature, but when he realizes it, he can change. On the other hand, the monk lies because of his understanding. He has spent years to learn, but he still desires an outcome.

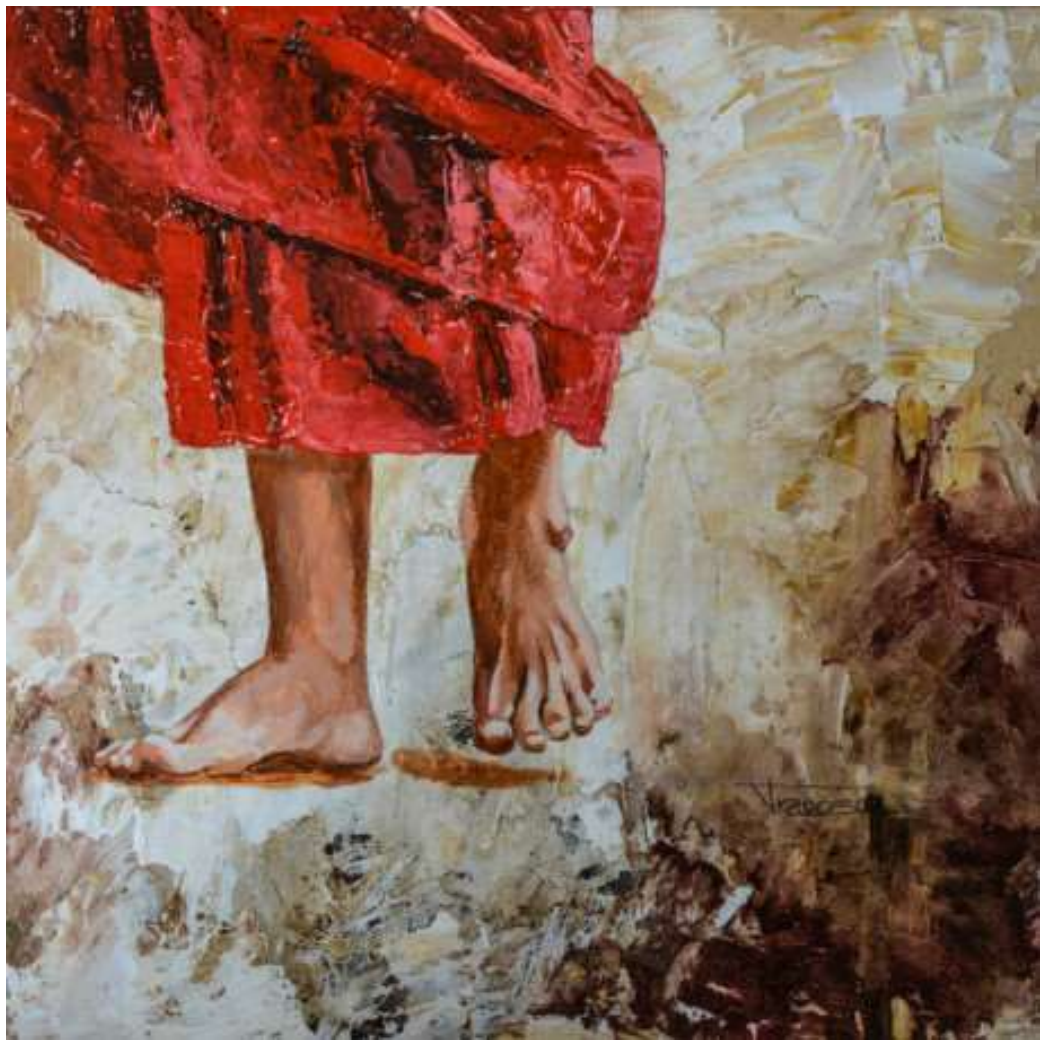

Francesca Escorbar's Buddhist Monk 2 (Source: Carré d'artistes)

A new preprint, which I was fortunate to be a part of, dives deep into this issue of lies and violence in Vietnamese folklores [2]. The results suggest lying that serves an either Confucianism, or Taoism religious mission brings a positive outcome to a character, while a violent act committed to serving Buddhist missions results in a happy ending for the committer. In fact, elements of violence and lies appear in folklore more often than we think. 
For instance, in "Little Red Riding Hood," the wolf eats the grandma, and he also eats the Little Red Riding Hood in some versions too. In "Hansel and Gretel," the two kids are abandoned by their parents, and later it is the sister who had to kill the witch. Alcantud-Diaz (2010) highlights that the classic Brothers Grimm collection of fairy tales contains an alarming amount of violent words, either directly or indirectly [3].

A fictional story often reflects reality and carries the culture of its creators. Studies of fictional stories have unearthed cultural phenomenon [4], or how we perceive environmental disasters [5]. For folklore like 'a story of a bird named Bìm Bịp,' it is often perceived as a story that our ancestors used to educate people. However, the cultural norms are also transmitted through the story. And, with all the lies, violence, our modern story is not so different.

\section{References:}

[1] Camus, A. (2005). The myth of Sisyphus. London, UK: Penguin Books. (Original work published in 1942).

[2] Vuong, Q.-H., La, V.-P., Ho, T. M., Nguyen, H.-K. T., Vuong, T. T., \& Ho, T. M. (2019, September 26). On how religions could accidentally incite lies and violence: Folktales as a cultural transmitter. OSF Preprints (Working Paper No. AISDL-1909), DOI: 10.31219/osf.io/nb7tg.

[3] Alcantud Díaz, M. (2010). Violence in the Brothers Grimm's fairy tales: a corpus-based approach. Revista Alicantina de Estudios Ingleses, 23, 173-185, DOI: 10.14198/raei.2010.23.10.

[4] Vuong, Q.-H., La, V.-P., Vuong, T. T., Nguyen, V. H., Ho, M. T., Nguyen, T. H. K., Bui, Q. K., Ho, M. T. (2018). Cultural additivity: Behavioural insights from the interaction of Confucianism, Buddhism, and Taoism in folktales. Palgrave Communications, 4, 143, DOI:10.1057/s41599-018-0189-2.

[5] Clode, D., \& Stasiak, M. (2014). Fictional depictions of climate change. International Journal of Climate Change, 5(4), 19-29. 